\title{
Functional characterization and kinetic studies of an ancestral lamprey GnRH-III selective type II GnRH receptor from the sea lamprey, Petromyzon marinus
}

\author{
M R Silver and S A Sower \\ Department of Biochemistry and Molecular Biology, University of New Hampshire, 46 College Road, Durham, New Hampshire 03824, USA \\ (Requests for offprints should be addressed to S A Sower; Email: sasower@ cisunix.unh.edu) \\ (M R Silver is now at Department of Inflammation, Wyeth Research, Cambridge, Massachusetts 02140, USA)
}

\begin{abstract}
The recently cloned lamprey $\mathrm{GnRH}$ receptor was shown to have several unique features, including the longest intracellular C-terminal tail (120 amino acids (aa)) of any previously described GnRH receptor. In the current study, a series of experiments were performed examining cAMP responses, binding kinetics, whole cell competitive binding assays and internalization studies of the lamprey $\mathrm{GnRH}$ receptor using a series of three C-terminal tail truncations ( 80 aa, 40 aa and 0 aa) to better describe the functional significance of this unique vertebrate $\mathrm{GnRH}$ receptor. Activation of the lamprey $\mathrm{GnRH}$ receptor was shown to stimulate cAMP production in a dose-dependant manner when treated with either lamprey $\mathrm{GnRH}-\mathrm{I}\left(\mathrm{LogEC}_{50}-6 \cdot 57 \pm 0 \cdot 15\right)$ or lamprey $\mathrm{GnRH}-\mathrm{III}\left(\mathrm{LogEC}_{50}-8 \cdot 29 \pm 0 \cdot 09\right)$. Truncation analysis indicated that the membrane proximal 40 aa of the lamprey $\mathrm{GnRH}$ receptor $\mathrm{C}$-terminal tail contain a motif required for cAMP accumulation. Saturation binding assays using the wild type and truncated lamprey $\mathrm{GnRH}$ receptors revealed that all of three truncated lamprey $\mathrm{GnRH}$ receptors were capable of binding lamprey $\mathrm{GnRH}-\mathrm{I}$. Competitive, intact cell-binding assays suggested that the lamprey $\mathrm{GnRH}$ receptor is lamprey $\mathrm{GnRH}-\mathrm{III}$ selective, based on the observed pharmacological profile: lamprey $\mathrm{GnRH}-\mathrm{III}$ (Inhibitory constant (Ki) $0 \cdot 708 \pm 0.245 \mathrm{nM}$ ) $=$ chicken $\mathrm{GnRH}-\mathrm{II}$ $(\mathrm{Ki} 0.765 \pm 0.160 \mathrm{nM})>$ mammalian $\mathrm{GnRH}(\mathrm{Ki} 12.9 \pm 1.96 \mathrm{nM})>$ dAla ${ }^{6}$ Pro ${ }^{9} \mathrm{NEt}$ mammalian $\mathrm{GnRH}(\mathrm{Ki} 21.6 \pm 9.68 \mathrm{nM})>$ lamprey $\mathrm{GnRH}-\mathrm{I}(\mathrm{Ki} 118.0 \pm 23 \cdot 6)$. Finally, the lamprey $\mathrm{GnRH}$ receptor was shown to undergo rapid ligand-dependant internalization, which was significantly diminished in the tail-less truncated form. We have shown from our current and our previous structural studies that this unique lamprey $\mathrm{GnRH}$ receptor shares several characteristics of both type I and type II GnRH receptors which suggests that this receptor has retained ancestral characteristics that can provide insight into the function and evolution of the vertebrate $\mathrm{GnRH}$ receptor family.
\end{abstract}

Journal of Molecular Endocrinology (2006) 36, 601-610

\section{Introduction}

The vertebrate hypothalamic-pituitary-gonadal axis is regulated by gonadotropin-releasing hormone $(\mathrm{GnRH})$, a decapeptide hormone that is produced and released from the hypothalamus. At the anterior pituitary, GnRH action is mediated through high affinity binding with the GnRH receptor, a class A or rhodopsin-like seven transmembrane G-protein coupled receptor (GPCR) (Millar et al. 2004). The GnRH receptor is unique among all GPCRs in that the type I mammalian GnRH receptors lack the highly conserved intracellular carboxy-terminal (C-terminal) tail, which has been shown to be a vital structural element required for several key functions, such as G-protein coupling and second messenger activation, ligand binding, cell surface expression and ligand-dependant internalization (Koenig \& Edwardson 1997, Heding et al. 1998, Blomenrohr et al. 1999, Bockaert et al. 2003, Ronacher et al. 2004). Based simply on the presence or absence of a C-terminal tail, the GnRH receptors can be divided into two groups; the type I tail-less GnRH receptors, which have only been identified in mammals and the C-terminal tailcontaining type II GnRH receptors, which have been identified across the vertebrate lineage (Okubo et al. 2001, Ikemoto et al. 2004, Silver et al. 2005).

GnRH receptor signaling has been characterized in several systems, and is primarily thought to function through the Inositol 1,4,5-triphospate $\left(\mathrm{IP}_{3}\right)$ second messenger pathway; however, type II GnRH receptors and in some cases type I GnRH receptors have been shown to also activate cAMP signaling (Arora et al. 1998, Stanislaus et al. 1998, Grosse et al. 2000, Liu et al. 2002, Oh et al. 2005). The presence or absence of the C-terminal tail in type II and type I GnRH receptors respectively could possibly explain the signaling disparity between the two groups, where, for example, histidinephenylalanine-arginine-lysine (an HFRK) motif in the membrane proximal region of bullfrog type II GnRH receptors was recently shown to be required for cAMP 
signaling (Oh et al. 2005). Rapid, ligand-dependant internalization resulting in desensitization and/or signal switching is another key functional difference between type I and type II GnRH receptors; this has been described and attributed to the presence or absence of specific Ser/Thr residues located throughout the C-terminal tail (Blomenrohr et al. 1999, Willars et al. 1999, Pawson et al. 2003, Ronacher et al. 2004).

As an agnathan, the oldest extant lineage of vertebrates, the sea lamprey has become a model system for analysis of the evolution of the neuroendocrine regulation of reproduction (Sower 2003). The lamprey expresses two forms of GnRH, lamprey GnRH-I and lamprey GnRH-III, both of which are produced in the hypothalamus and have been shown to regulate the reproductive axis (Sherwood et al. 1986, Sower et al. 1993, Deragon \& Sower 1994, Suzuki et al. 2000, Silver et al. 2004). Recently, a GnRH receptor cDNA was cloned from the sea lamprey, Petromyzon marinus; this contained a C-terminal tail of 120 amino acids (aa), the longest of any previously described $\mathrm{GnRH}$ receptor to date (Silver et al. 2005). To better describe the lamprey GnRH receptor, a series of functional and pharmacological assays was performed in the current study, including examination of cAMP responses, analysis of receptor binding kinetics, whole cell competitive binding assays and internalization studies using a series of C-terminal tail truncations to better our understanding of the significance of certain regions of the lengthy C-terminal tail, as well as functional aspects of the receptor. The lamprey GnRH receptor was shown to stimulate the cAMP signaling system in a dosedependant manner, which, through mutagenesis studies, was shown to depend on the presence of the $\mathrm{G}$-terminal tail. The $\mathrm{C}$-terminal tail was also shown to be required for rapid ligand-dependant internalization, binding affinity and, to some degree, cell surface expression. Finally, pharmacological profiling, in conjunction with these and previous efficacy data has confirmed that the lamprey GnRH receptor is lamprey GnRH-III selective. These data indicate that the lamprey $\mathrm{GnRH}$ receptor shares several characteristics of both type I and type II GnRH receptors and likely retains ancestral characteristics of the vertebrate GnRH receptor family.

\section{Materials and methods}

Cell culture, construct development and transfection

COS7 cells (American Type Culture Collection, Manassas, VA, USA) were maintained in $10 \%$ fetal bovine serum in Dulbecco's modified Eagle's medium (DMEM) at $37^{\circ} \mathrm{C}$ in $5 \% \mathrm{CO}_{2}$. The coding regions of the wild type and mutant lamprey $\mathrm{GnRH}$ receptor (GenBank Accession Number AF439802) (see Fig. 1) were inserted into the pcDNA3.1 mammalian expression vector (Invitrogen, Carlsbad, CA, USA). The lamprey GnRH receptor open reading frames (ORFs) were amplified via PCR using the Advantage2 PCR system (CLONTEGH, Mountain View, CA, USA) with the lamprey GnRH receptor ORF 5' (5'-CAC CAT GGA AGG CAT CAA CAT GAA CAT GAC-3') combined with either the lamprey GnRH receptor ORF $3^{\prime}$ (to produce the wild type ORF: 5'-TCA GAT GCAGCA GCT TTC AGG ACA TAC GAG AG-3'), lamprey GnRH receptor 80 aa $3^{\prime}$ (to produce the lamprey $\mathrm{GnRH}$ receptor with an 80 aa G-terminal tail: TCA-TGC-CGC-TCT-GTT-CAC-GGG-GAG), lamprey $\mathrm{GnRH}$ receptor 40 aa 3' (to produce the lamprey GnRH receptor with a 40 aa C-terminal tail: TCA-ACT-CGG-CAC-GGA-CGA-GGC-CGA) or the lamprey GnRH receptor 0 aa 3' (to produce the tail-less lamprey GnRH receptor: TCA-CGG-CGC-GAA-CACGCG-GTA-GAT). The day prior to transfection, $5 \times 10^{5}$ cells were seeded in $60 \mathrm{~mm}$ culture plates. Transfection was performed using $5 \mu \mathrm{g}$ vector and $15 \mu \mathrm{l}$ Lipofectamine (Invitrogen) in $2.4 \mathrm{ml}$ total volume in Opti-MEM-I (Invitrogen) per culture. Transfection efficiency was optimized using a lacZ insert, while transcription consistency was measured using RT-PCR after transfection with either the wild type or mutant lamprey GnRH receptors.

\section{Lamprey GnRH receptor cAMP assay}

The day after transfection, cells were trypsinized, 96-well plates were seeded with $5 \times 10^{4}$ cells/well and cultures were grown overnight. On day 3 , cells were stimulated with either control (ID buffer $-1.0 \mathrm{mM}$ 3-isobutyl1-methylxanthine in DMEM), lamprey GnRH-I (American Peptide Company, Sunnyvale, CA, USA) or lamprey GnRH-III (American Peptide Company) in ID buffer (concentrations ranging from $10^{-4} \mathrm{M}$ to $10^{-10} \mathrm{M}$ for dose-response analysis or $10^{-5} \mathrm{M}$ for the $\mathrm{C}$-terminal tail functional analysis) for $1 \mathrm{~h}$ at $37^{\circ} \mathrm{C}$. Treatments were performed in triplicate and cells transfected with blank vector were used as negative controls. cAMP assays were performed using the BioTrak enzymeimmunoassay system (Amersham), according to the manufacturer's instructions. Analyses were performed using Prism (GraphPad, San Diego, CA, USA).

\section{Whole cell lamprey GnRH receptor saturation binding assay}

Saturation binding assays were performed using adherent, intact cells with ${ }^{125}$ I-labeled lamprey GnRH-I. ${ }^{125}$ I-Labeled lamprey GnRH-I was iodinated using a modification of the chloramine-T method, which was purified as described by Stopa et al. (1988). Note that lamprey GnRH-III was not used as the radioligand since 


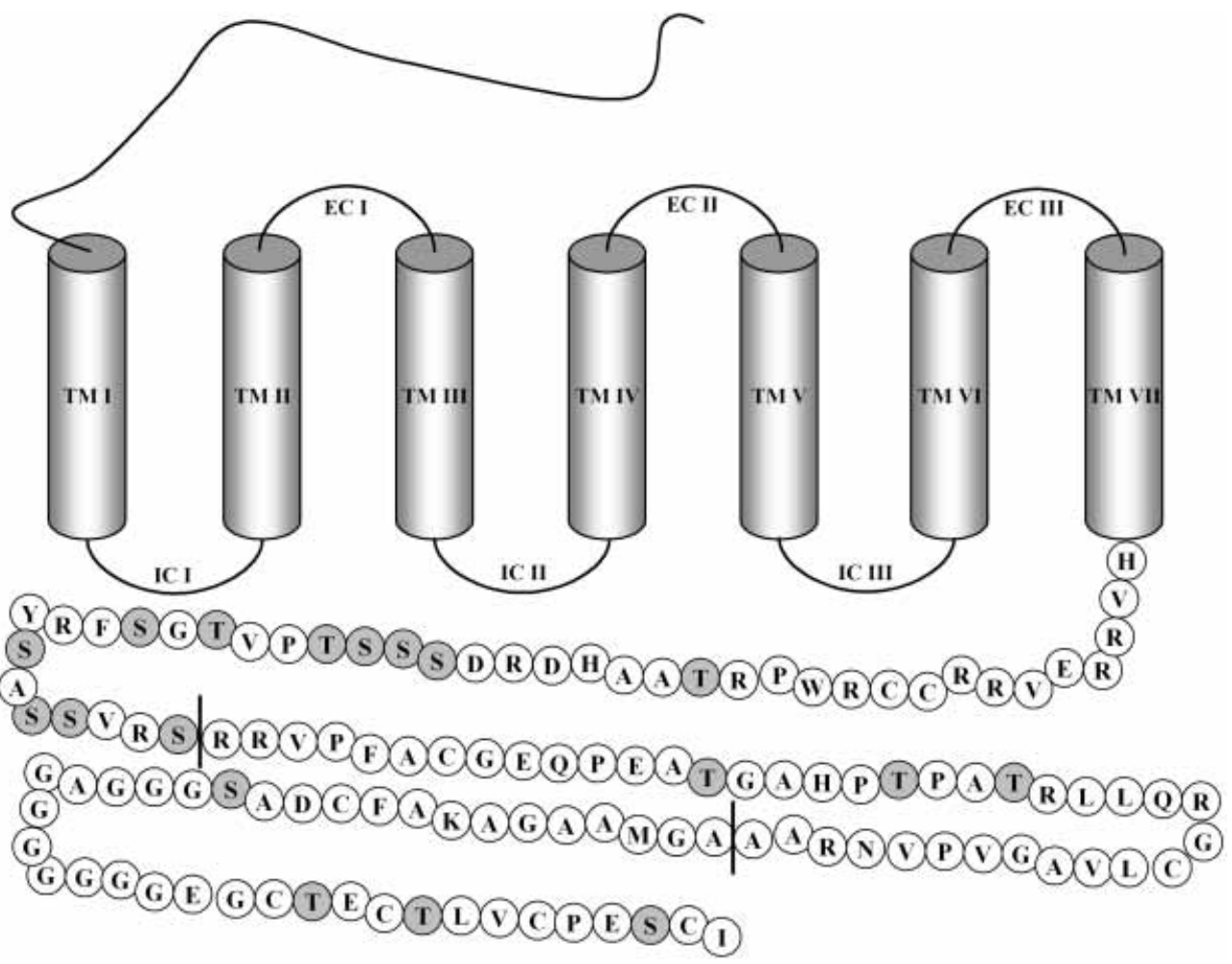

Figure 1 Lamprey GnRH receptor structure and truncation demarcation. The lamprey $\mathrm{GnRH}$ receptor $\mathrm{C}$-terminal tail of 120 aa is the longest of any known $\mathrm{GnRH}$ receptor. Several putative phosphorylation sites are located within the C-terminal tail, which are shown highlighted in gray. Black lines represent cutoff points within the sequence used to develop vectors containing C-terminal tail truncations to include the wild type (120 aa tail), 80 aa tail, 40 aa tail or tail-less ( 0 aa tail) mutants. TM, transmembrane; EC, extracellular; IC, intracellular.

it cannot be iodinated due to the lack of a Tyr residue. For saturation binding assays, the day after transfecting COS7 cells with either the wild type or mutant lamprey GnRH receptors, $1 \times 10^{5}$ cells were seeded into 24-well plates in $500 \mu \mathrm{l}$ medium; these were grown for 2 days at $37^{\circ} \mathrm{C}$ in $5 \% \mathrm{CO}_{2}$. Cells were then washed once in $500 \mu \mathrm{l}$ assay buffer $(25 \mathrm{mM}$ HEPES-modified DMEM with $0 \cdot 1 \% \mathrm{BSA}$ ), followed by incubation with increasing concentrations of ${ }^{125}$ I-labeled lamprey GnRH-I (1$100 \mathrm{nM}$ ), in $200 \mu \mathrm{l}$ total volume of assay buffer, for $3.5 \mathrm{~h}$ on ice at $4{ }^{\circ} \mathrm{C}$. Non-specific binding (NSB) was determined using cells incubated with both ${ }^{125}$ I-labeled lamprey GnRH-I and $10 \mu \mathrm{M}$ cold lamprey GnRH-III. After $3.5 \mathrm{~h}$, cells were quickly washed twice with $500 \mu \mathrm{l}$ ice-cold PBS and cells were examined using an inverted microscope to ensure that no cells were lost. Cells were solubilized with $300 \mu \mathrm{l} 0.5 \mathrm{M} \mathrm{NaOH}, 0 \cdot 1 \% \mathrm{SDS}$, and bound ${ }^{125}$ I-labeled lamprey GnRH-I was counted using a $\gamma$-counter. All total binding samples were run in triplicate, NSBs were run in duplicate, and each independent experiment was repeated two to three times. Data were analyzed using Prism (GraphPad).

\section{Competitive binding analysis}

Competitive binding properties of lamprey GnRH-I, lamprey GnRH-III, chicken GnRH-II (Peninsula Laboratories, San Carlos, CA, USA), mammalian GnRH (Peninsula Laboratories) and $\mathrm{DAla}^{6} \mathrm{Pro}^{9} \mathrm{NEt} \mathrm{mGnRH}$ (Peninsula Laboratories) were performed using COS7 cells transfected with the wild type lamprey GnRH receptor. Cells were prepared as described above; however, the ${ }^{125}$ I-labeled lamprey GnRH-I concentration was held constant at $10 \mathrm{nM}$, with either assay buffer (total binding) or increasing concentrations of cold competing ligand in assay buffer (ranging from $10^{-13} \mathrm{M}$ to $10^{-6} \mathrm{M}$ ) in $200 \mu \mathrm{l}$ total volume for $3.5 \mathrm{~h}$ on ice in the $4{ }^{\circ} \mathrm{C}$ incubator. Cells were washed and processed as described above. All samples were run in triplicate, in three independent experiments. Data were analyzed using Prism (GraphPad).

\section{Lamprey GnRH receptor internalization assay}

Internalization of ${ }^{125}$ I-labeled lamprey GnRH-I was performed based on the acid-wash method, as previously 


\section{LGnRH-R cAMP Dose Response}

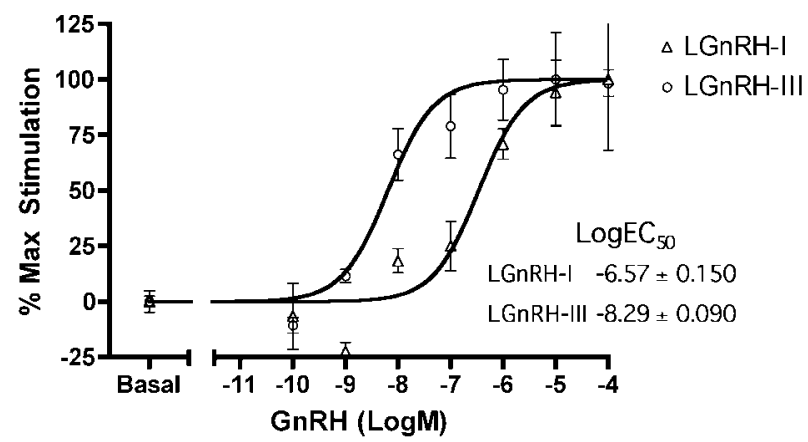

Figure 2 cAMP dose-response curve. The lamprey $\mathrm{GnRH}$ receptor was shown to activate the cAMP signaling system in a dose-dependant manner. Lamprey (L) GnRH-III was a significantly more potent activator of the lamprey $\mathrm{GnRH}$ receptor relative to lamprey $\mathrm{GnRH}-\mathrm{I}$. A representative curve from three independent experiments is shown; $\operatorname{LogEC}_{50}$ is shown as means \pm S.E.M.; $n=3$.

described (Hazum et al. 1983, Pawson et al. 1998, King et al. 2000). Briefly, COS7 cells transfected with the wild type lamprey GnRH receptor or C-terminal tail truncated mutants were seeded $\left(1 \times 10^{5}\right.$ cells $)$ in 24 -well plates in $500 \mu \mathrm{l}$ medium, and were grown for $48 \mathrm{~h}$. Cells were incubated with $10 \mathrm{nM}{ }^{125}$-labeled lamprey GnRH-I on ice at $4{ }^{\circ} \mathrm{C}$ for $3.5 \mathrm{~h}$. Cells were then immediately brought to $37^{\circ} \mathrm{C}$ for increasing periods of time. At the end of each time-point, cells were placed on ice and washed twice with $500 \mu \mathrm{l}$ ice-cold PBS. Acid-sensitive (surface bound) ${ }^{125}$ I-labeled lamprey GnRH was washed away by the addition of $0.3 \mathrm{ml}$ acid solution $(150 \mathrm{mM} \mathrm{NaCl}, 50 \mathrm{mM}$ acetic acid, $\mathrm{pH} 2 \cdot 8$ ) for $12 \mathrm{~min}$. The acid wash was removed, and acid insensitive (internalized) ligand was recovered using solubilizing reagent $(0.5 \mathrm{M} \mathrm{NaOH}$ with $0 \cdot 1 \%$ SDS). Both acid-sensitive and -insensitive binding was quantified with a $\gamma$-counter, and percent internalization was determined based on comparison of internalized ligand to total cell-associated ligand (internalized+surface bound). NSBs were determined using non-transfected cells. Treatments were performed in triplicate, and independent experiments were run three times for each receptor construct. Data were analyzed using Prism (GraphPad).

\section{Results}

\section{Lamprey GnRH receptor cAMP activation}

Both lamprey GnRH-I and lamprey GnRH-III stimulated a significant response in cAMP accumulation, in a dose-dependant manner, in COS7 cells that were transiently transfected with the lamprey $\mathrm{GnRH}$ receptor (Fig. 2). The $\operatorname{LogEC}_{50}$ (represented as means \pm S.E.M.; $n=3)$ of lamprey GnRH-III $(-8 \cdot 47 \pm 0 \cdot 046)$ was

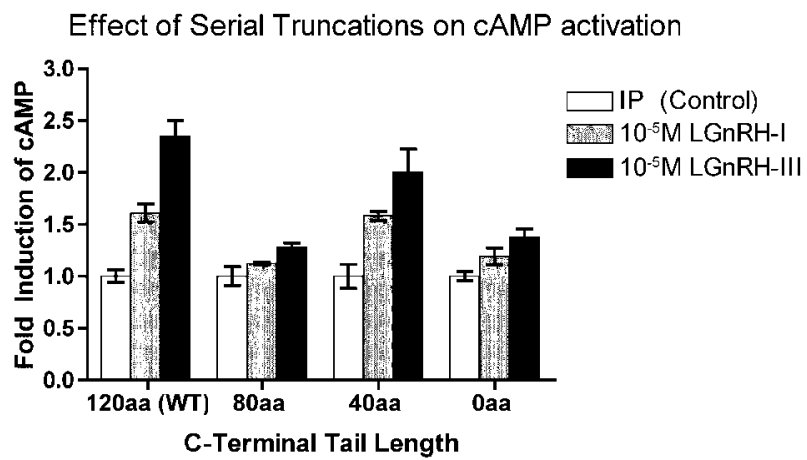

Figure 3 Effect of lamprey $\mathrm{GnRH}$ receptor C-terminal tail truncations on cAMP signaling. CAMP accumulation assay using wild type (WT) and mutant lamprey $\mathrm{GnRH}$ receptors containing $\mathrm{C}$-terminal tail truncations treated with a maximum dose $\left(10^{-5} \mathrm{M}\right)$ of either lamprey (L) GnRH-I or lamprey $\mathrm{GnRH}-\mathrm{III}$ are shown relative to fold stimulation. Lamprey $\mathrm{GnRH}-$ III simulates a greater magnitude of cAMP signaling compared with lamprey $\mathrm{GnRH}-\mathrm{I}$ in the wild type receptor. Truncation of the C-terminal tail reduced cAMP accumulation, which was not recovered in the tail-less mutant form.

significantly $(P<0.0001)$ lower then the $\operatorname{LogEC}_{50}$ of lamprey GnRH-I ( $-6 \cdot 59 \pm 0 \cdot 082)$. This approximately 50 -fold difference suggests that the presently cloned lamprey GnRH-R is lamprey GnRH-III selective. Cells transfected with blank pcDNA3 1 vector did not respond to treatment with either lamprey GnRH-I or lamprey GnRH-III (data not shown).

Consistent with this difference in $\mathrm{LogEC}_{50}$, lamprey GnRH-III stimulated a larger magnitude of cAMP accumulation, compared with lamprey GnRH-I, when the wild type or mutant lamprey GnRH receptors were treated with a maximum dose $\left(10^{-5} \mathrm{M}\right)$ (Fig. 3 or Table 1). Stimulation of the wild type lamprey GnRH receptor led to a $1.68 \pm 0.073$-fold increase in response to lamprey GnRH-I and a 2.11 $\pm 0 \cdot 162$-fold increase in response to lamprey GnRH-III. Serial truncation of the lamprey $\mathrm{GnRH}$ receptor led to a drastic decrease in the magnitude of cAMP accumulation, whereas the stimulation of the 80 aa C-terminal tail resulted in $1 \cdot 26 \pm 0 \cdot 204$ - and $1 \cdot 36 \pm 0 \cdot 117$-fold increases in response to lamprey GnRH-I and lamprey GnRH-III respectively. Further truncation of the G-terminal tail to 40 aa resulted in a recovery of cAMP accumulation $(1 \cdot 77 \pm 0 \cdot 242$-fold for lamprey GnRH-I and $2 \cdot 19 \pm$ 0.262-fold increases for lamprey GnRH-III); however, the tail-less mutant showed a drastic reduction in ability to activate the cAMP system $(1 \cdot 26 \pm 0 \cdot 056$-fold increase in response to lamprey GnRH-I and 1.30 $\pm 0 \cdot 059$-fold increase in response to lamprey GnRH-III).

\section{Pharmacological characterization}

Binding of ${ }^{125}$ I-labeled lamprey GnRH-I to intact, adherent COS7 cells transfected with the lamprey 
Table 1 Lamprey (L) GnRH receptor C-terminal tail truncations: function and pharmacology. Values are means \pm S.E.M.

\begin{tabular}{|c|c|c|c|c|}
\hline & \multicolumn{2}{|c|}{ cAMP accumulation } & \multicolumn{2}{|c|}{ Binding kinetics } \\
\hline & LGnRH-I & LGnRH-III & $K_{\mathrm{d}}(\mathrm{nM})$ & $B_{\max }(f \mathrm{~mol} /$ well $)$ \\
\hline \multicolumn{5}{|l|}{ Construct } \\
\hline Wild type (120 aa tail) & $1.68 \pm 0.073$ & $2 \cdot 39 \pm 0.162$ & $31 \cdot 1 \pm 10 \cdot 3$ & $394 \cdot 6 \pm 52 \cdot 1$ \\
\hline 80 aa tail & $1 \cdot 26 \pm 0 \cdot 204$ & $1 \cdot 36 \pm 0 \cdot 117$ & $51 \cdot 7 \pm 18 \cdot 4$ & $276 \cdot 1 \pm 46 \cdot 9$ \\
\hline 40 aa tail & $1.77 \pm 0.242$ & $2 \cdot 19 \pm 0 \cdot 262$ & $85 \cdot 4 \pm 5 \cdot 3$ & $1906 \pm 67 \cdot 1$ \\
\hline Tail-less & $1.26 \pm 0.056$ & $1 \cdot 30 \pm 0.059$ & $72 \cdot 3 \pm 19 \cdot 8$ & $774.5 \pm 140.9$ \\
\hline
\end{tabular}

GnRH receptor was saturable with a $B_{\max }$ of $394 \cdot 6 \mathrm{fmol} /$ well and a $K_{\mathrm{d}}$ of $31 \cdot 1 \mathrm{nM}$. This relatively high $K_{\mathrm{d}}$ was expected, given that this receptor is lamprey GnRH-III selective. Binding of ${ }^{125}$ I-labeled lamprey GnRH-I to the C-terminal tail truncated mutant lamprey GnRH receptors was also saturable (see Fig. 4 or Table 1), whereas the 80 aa tail mutant had a $B_{\max }$ of $276 \mathrm{fmol} /$ well and a $K_{\mathrm{d}}$ of $51.7 \mathrm{nM}$, the 40 aa tail mutant had a $\mathrm{B}_{\max }$ of $1906 \mathrm{fmol} /$ well and a $K_{\mathrm{d}}$ of $85 \mathrm{nM}$, while the 0 aa tail-less mutant had a $\mathrm{B}_{\max }$ of $775 \mathrm{fmol} /$ well and a $K_{\mathrm{d}}$ of $72 \mathrm{nM}$. C-terminal tail truncations resulted in an increase in cell surface expression of the 40 aa C-terminal tail $(483.0 \%$ of wild type) and tail-less mutants (196.4\% of wild type), while the 80 aa C-terminal tail mutant expression decreased (69.9\% of wild type). In all cases, the truncations resulted in an increase in $K_{\mathrm{d}}, 80$ aa tail (166.2\% of wild type), 40 aa tail $(273 \cdot 3 \%$ of wild type) and tail-less $(231.5 \%$ of wild type).

COS7 cells transfected with the wild type lamprey GnRH receptor were used in a series of competitive binding assays in order to describe the binding affinity of different GnRH isoforms. Assays using intact, adherent

\section{Intact Cell Saturation Binding}

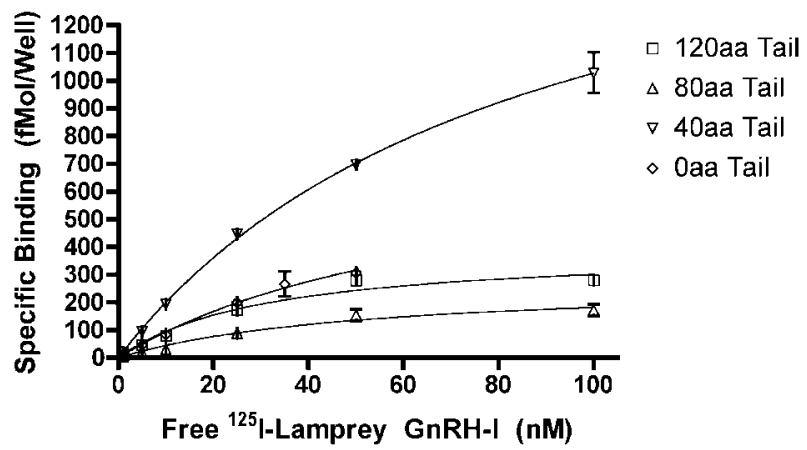

Figure 4 Saturation binding analysis. Saturation binding analysis of ${ }^{125}$-labeled lamprey $\mathrm{GnRH}-\mathrm{I}$ using adherent, intact COS7 cells transfected with the wild type lamprey $\mathrm{GnRH}$ receptor, 80 aa tail, 40 aa tail or tail-less mutants. Data are shown as means \pm S.E.M. $(n=3)$, representing two to three independent experiments. cells were performed holding ${ }^{125}$ I-labeled lamprey GnRH-I constant at $10 \mathrm{nM}$ with increasing concentrations of cold competitor, ranging from $10^{-13} \mathrm{M}$ to $10^{-6} \mathrm{M}$. These competitive binding analyses indicated that the wild type lamprey $\mathrm{GnRH}$ receptor is lamprey GnRH-III selective (Fig. 5), with a pharmacological profile of lamprey GnRH-III $(\mathrm{Ki}=0 \cdot 708 \pm 0 \cdot 245 \mathrm{nM})=$ chicken GnRH-II $(\mathrm{Ki}=0 \cdot 765 \pm 0 \cdot 160 \mathrm{nM})>$ mammalian GnRH $\quad(\mathrm{Ki}=12.9 \pm 1.96 \mathrm{nM})>\mathrm{DAla}^{6}$ Pro $^{9} \mathrm{NEt}$ mammalian $\mathrm{GnRH}(\mathrm{Ki}=21 \cdot 6 \pm 9 \cdot 68 \mathrm{nM})>$ lamprey GnRH-I $(118 \cdot 0 \pm 23 \cdot 6)$ (see Table 2).

\section{Lamprey GnRH receptor internalization}

Internalization of ${ }^{125}$ I-labeled lamprey GnRH-I was used to characterize the effect of C-terminal tail length on the rate of ligand-dependant internalization, which is described as the percent of total cell-associated ligand, and fit using a single component exponential equation $\left(\mathrm{Y}=\mathrm{Y}_{\max }\left(1-\mathrm{e}^{\mathrm{kt}}\right) ; \mathrm{y}=\%\right.$ internalized, $\mathrm{k}=\%$ internalized/ min and $t=$ time in min (see Fig. 6). The wild type lamprey $\mathrm{GnRH}$ receptor was rapidly internalized in

\section{LGnRH Receptor Competitive Binding}

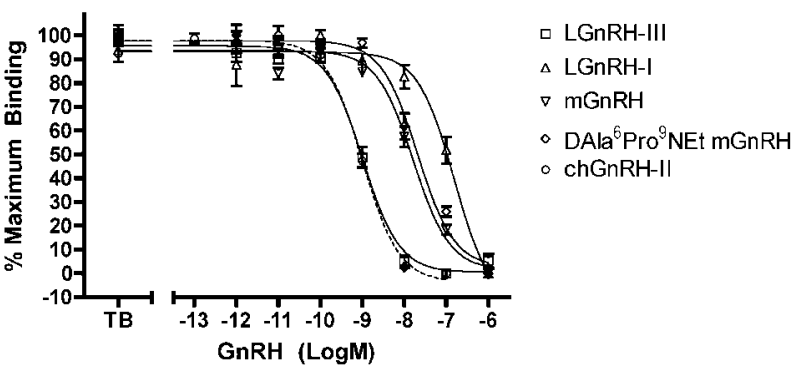

Figure 5 Lamprey GnRH receptor pharmacological profile. Competitive binding analysis of ${ }^{125}$-labeled lamprey GnRH-I using intact adherent COS7 cells transfected with the wild type lamprey $\mathrm{GnRH}$ receptor incubated with increasing concentrations of lamprey (L) GnRH-III, lamprey $\mathrm{GnRH}-\mathrm{I}$, mammalian $(m)$ GnRH, dAla ${ }^{6}$ Pro ${ }^{9}$ NEt mammalian $\mathrm{GnRH}$ or chicken (ch) GnRH-II. Data shown as means \pm S.E.M. $(n=3)$ of $\%$ maximum binding demonstrate a binding preference for lamprey $\mathrm{GnRH}-\mathrm{III}$, which was equal to chicken $\mathrm{GnRH}-\mathrm{II}>$ mammalian $\mathrm{GnRH}>\mathrm{dAla}^{6} \mathrm{Pro}^{9} \mathrm{NEt}$ mammalian $\mathrm{GnRH}>$ lamprey $\mathrm{GnRH}-\mathrm{I}$. 
Table 2 Summary of lamprey $(\mathrm{L}) \mathrm{GnRH}$ receptor efficacy and pharmacological profiling. Values are means \pm S.E.M.

\begin{tabular}{|c|c|c|c|}
\hline & \multicolumn{3}{|c|}{ Lamprey GnRH receptor characterization } \\
\hline & $\operatorname{LogEC}_{50}$ & $\log C_{50}$ & $\mathrm{Ki}(\mathrm{nM})$ \\
\hline \multicolumn{4}{|l|}{ GnRH form } \\
\hline IGnRH-III & $-8 \cdot 29 \pm 0.09$ & $-8 \cdot 99 \pm 0 \cdot 0922$ & $0 \cdot 708 \pm 0 \cdot 245$ \\
\hline IGnRH-I & $-6 \cdot 57 \pm 0.15$ & $-6 \cdot 81 \pm 0 \cdot 116$ & $118 \cdot 0 \pm 23 \cdot 6$ \\
\hline chGnRH-II & - & $-8.96 \pm 0.0713$ & $0.765 \pm 0.16$ \\
\hline $\mathrm{mGnRH}$ & - & $-7 \cdot 79 \pm 0 \cdot 147$ & $12 \cdot 9 \pm 1.96$ \\
\hline $\mathrm{mGnRHa}$ & - & $-7 \cdot 68 \pm 0 \cdot 116$ & $21 \cdot 6 \pm 9 \cdot 68$ \\
\hline
\end{tabular}

mGnRHa, DAla ${ }^{6}$ Pro ${ }^{9} \mathrm{NEt}$ mammalian $\mathrm{GnRH}$; ch, chicken; $\mathrm{m}$, mammalian.

response to treatment with $10 \mathrm{nM}{ }^{125}$ I-labeled lamprey GnRH-I. Within the first $10 \mathrm{~min}$ at $37^{\circ} \mathrm{C}$, approximately $63 \%$ of the cell-associated radioligand was found in the intracellular fraction. Lamprey $\mathrm{GnRH}$ receptor mutants with C-terminal tail truncations were used to identify regions containing motifs that are required for rapid ligand-dependant internalization. Truncation of the C-terminal tail to 80 aa or 40 aa had no effect on either the rate or extent of internalization when compared with wild type. The tail-less lamprey GnRH receptor, however, showed a marked reduction in ligand-dependent internalization, with a $\mathrm{Y}_{\max }$ of $28.9 \%$, a drastic reduction compared with the wild type or other truncated mutants.

\section{Discussion}

The GnRH receptor from the sea lamprey, Petromyzon marinus, a member of the oldest extant lineage of vertebrates, the agnathans, was used in a series of functional and pharmacological experiments in order to investigate and better define how the function of the GnRH receptor family has evolved across vertebrates. Stimulation of the lamprey GnRH receptor was shown to activate cAMP production; however, this activation was shown to require the first 40 aa of the $\mathrm{C}$-terminal tail. Since the truncated tail-less mutant lamprey GnRH receptor was capable of ligand binding we propose that $\mathrm{G} \alpha_{\mathrm{s}}$ coupling requires a motif within the first 40 aa of the C-terminal tail. Pharmacological profiling indicated that the lamprey GnRH receptor is lamprey GnRH-III selective, with an equal affinity for lamprey GnRH-III and chicken GnRH-II. The wild type, 80 aa C-terminal tail mutant and 40 aa C-terminal tail mutant lamprey GnRH receptors were shown to undergo rapid, ligand-dependant internalization, but the tail-less mutant was not, indicating a motif within the first 40 aa that is required for this process. This unique lamprey $\mathrm{GnRH}$ receptor has high affinity for both lamprey GnRH-III
LGnRH Receptor Internalization

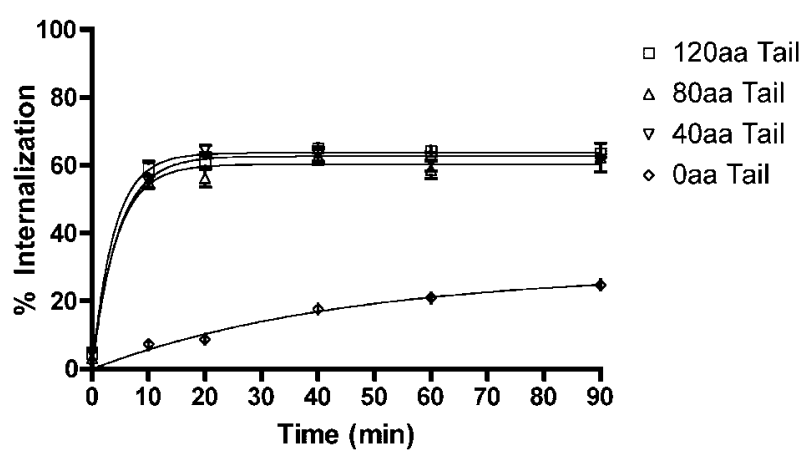

Figure 6 Internalization profile. ${ }^{125}$ I-Labeled lamprey $\mathrm{GnRH}-\mathrm{I}$ mediated internalization of the wild type lamprey $\mathrm{GnRH}$ receptor, 80 aa tail, 40 aa tail or tail-less mutants in transiently transfected COS7 cells. Treatments were brought to steady state on ice and then rapidly brought to $37^{\circ} \mathrm{C}$ for increasing periods of time. Percent internalization was calculated as a measurement of internalized radioligand relative to the total cell-associated radioligand. Data are shown as means \pm S.E.M. $(n=3)$, representing two to three independent experiments.

and chicken GnRH-II and ligand-binding activity when truncated to a tail-less form.

Unique among the approximately 1000 GPCR encoding genes in the human genome (Fredriksson et al. 2003), the type I GnRH receptor lacks an intracellular G-terminal tail, which is thought to be involved in G-protein coupling, cell surface expression and internalization (Blomenrohr et al. 1999, Vrecl et al. 2000, Ronacher et al. 2004). Interestingly, tail-less or type I GnRH receptors have only been identified in mammals, while type II GnRH receptors, which contain C-terminal tails, have been cloned from species across the vertebrate lineage, suggesting a recent, rapid evolutionary history (Sealfon et al. 1997, Millar et al. 2004). A comparative analysis of GnRH receptors across the vertebrate lineage can provide significant insight into the molecular evolution of this receptor family. In this light, the GnRH receptor from the sea lamprey, Petromyzon marinus (Silver et al. 2005), provides an ideal model to analyze basal, or ancestral-like functions and functional elements that are involved in ligand binding, signaling and internalization.

Pituitary GnRH receptors are thought to primarily signal through $\mathrm{Ga} \alpha_{\mathrm{q} / 11}$, resulting in the stimulation of the $\mathrm{IP}_{3}$ second messenger system; however, $\mathrm{G} \alpha_{\mathrm{s}}$ activation and cAMP signaling has been reported as well (Arora et al. 1998, Stanislaus et al. 1998, Grosse et al. 2000, Liu et al. 2002, Oh et al. 2005). G-protein coupling to type I GnRH receptors clearly occurs within the intracellular loops (ILs), where several motifs have been identified that may be involved in G-protein coupling (see Table 3). For instance, the DRxxxI/VxxPL motif in IL2 and a conserved Ala residue in IL3 have been linked to $\mathrm{G \alpha}_{\mathrm{q} / 11}$ 
Table $3 \mathrm{GnRH}$ receptor $(\mathrm{R})$ domains involved in G-protein coupling

\begin{tabular}{|c|c|c|c|}
\hline & G-protein & Region involved in G-protein coupling & Reference \\
\hline \multicolumn{4}{|l|}{ Receptor } \\
\hline Mouse GnRH-R & $\mathrm{G} \alpha \mathrm{S}$ & IL1 (K71LKSR75; L58; L80) & Arora et al. (1998) \\
\hline Mouse GnRH-R & $\mathrm{G} \alpha \mathrm{q} / 11$ & IL2 (L147) & Arora et al. (1995) \\
\hline Mouse GnRH-R & $\mathrm{G} \alpha \mathrm{q} / 11$ & IL2 (DRS) & $\begin{array}{l}\text { Arora et al. (1997) and } \\
\text { Kitanovic et al. (2001) }\end{array}$ \\
\hline Mouse GnRH-R & $\mathrm{G} \alpha q / 11$ & IL3 (Leu237) & Chung et al. (1999) \\
\hline Rat GnRH-R & $\begin{array}{l}\mathrm{G} \alpha \mathrm{q} / 11 \text { and } \\
\mathrm{G} \alpha \mathrm{S}\end{array}$ & IL3 & Ulloa-Aguire et al. (1998) \\
\hline Rat GnRH-R & $\mathrm{G} \alpha \mathrm{q} / 11$ & C-terminus (F325S326L327) & Brothers et al. (2002) \\
\hline Human GnRH-R & $\mathrm{G} \alpha \mathrm{q} / 11$ & IL3 (A261) & Myburgh et al. (1998) \\
\hline Bullfrog GnRH-R1 & $\mathrm{G} \alpha \mathrm{S}$ & C-T (membrane proximal HFRK) & Oh et al. (2005) \\
\hline Lamprey GnRH-R & $\mathrm{G} \alpha \mathrm{q} / 11$ & IL1, 2 or 3 (activated by tail-less mutant) & Silver et al. (2005) \\
\hline Lamprey GnRH-R & $\mathrm{G} \alpha \mathrm{S}$ & $\mathrm{C}-\mathrm{T}$ (within first $40 \mathrm{aa}$ ) & Presented here \\
\hline
\end{tabular}

C-T, C-terminal tail; C-terminus refers to the C-terminal amino acids of the tail-less type $\mathrm{GnRH}$ receptors.

coupling (Arora et al. 1995, Myburgh et al. 1998), while a $\mathrm{BBxxB}$ (where $\mathrm{B}$ is any basic amino acid) in ILl was shown to be required for $\mathrm{G} \alpha_{\mathrm{s}}$ coupling (Arora et al. 1998). Furthermore, the presence or absence of the C-terminal tail in the type II or type I GnRH receptors could possibly explain the signaling disparity between the two groups, whereas an HFRK motif in the membrane proximal region of the bullfrog type II GnRH receptor- 1 was recently shown to be required for cAMP signaling, but not for Inositol phosphate (IP) signaling (Oh et al. 2005). In the present study, lamprey GnRH receptor was shown to activate the cAMP signaling system, in a dose-dependent manner, in transiently transfected COS7 cells. Lamprey GnRH-III was a more potent activator of this system compared with lamprey GnRH-I, which supports the previous hypothesis, based on IP activation (Silver et al. 2005), that the lamprey GnRH receptor is lamprey GnRH-III selective. These data have several interesting implications. The lamprey GnRH receptor activates both the cAMP and IP signaling systems; however, the IP system is activated at an approximately 10-fold lower concentration of both lamprey GnRH-I and lamprey GnRH-III, and is also activated to a greater magnitude of approximately $4 \cdot 5$-fold, compared with $\sim 1 \cdot 7$-fold (lamprey GnRH-I) or $\sim 2 \cdot 1$-fold (lamprey GnRH-III) (see Fig. 3) accumulation of cAMP. Not unexpectedly, truncation of the lamprey $\mathrm{GnRH}$ receptor $\mathrm{C}$-terminal tail interfered with cAMP signaling; this is partially recovered by the 40 aa tail mutant, and lost again in the tail-less mutant form. The exact nature of GPCR/Gprotein coupling is still in question since no conserved motifs that can be generally used to define G-protein specificity have been identified, nor has any particular domain been shown to be required. These current data indicate that a motif within the first 40 aa of the lamprey $\mathrm{GnRH}$ receptor is involved in the $\mathrm{G}_{\mathrm{s}}$ coupling, which we propose to be the 'HFRK'-like motif (histidine-valine-arginine-arginine (HVRR) in lamprey) located within the membrane proximal region of the C-terminal tail. Furthermore, this region contains a $\operatorname{BBxxB}(\mathrm{B}$ is any basic amino acid), which has been shown to be involved in $G \alpha_{\mathrm{s}}$ coupling in type I GnRH receptors, in which case this motif is located in the first IL (Arora et al. 1998).

The pharmacological profile of the lamprey $\mathrm{GnRH}$ receptor, as shown in Fig. 5 and Table 2, confirms the hypothesis that the lamprey GnRH receptor is lamprey GnRH-III selective, and furthermore supports the hypothesis that the lamprey expresses at least one additional, lamprey GnRH-I selective receptor, as previously described based on quantitative in vitro autoradiography (Knox et al. 1994) and IP signaling efficacy (Silver et al. 2005). The equivalent affinity for lamprey GnRH-III and chicken GnRH-II for this ancestral vertebrate $\mathrm{GnRH}$ receptor implies that perhaps they represent ancestral forms of $\mathrm{GnRH}$, as previously suggested (Sherwood et al. 1997, Sower 1997); nonetheless, more data would be required to confirm this hypothesis.

Efficacy data on their own can be difficult to interpret and misleading; however, in conjunction with binding affinity studies they can provide invaluable insight into the molecular mechanisms of GPCR function. The effects of lamprey $\mathrm{GnRH}$ receptor C-terminal tail truncations on binding affinity and cell surface expression showed that perturbation of the $\mathrm{G}$-terminal tail increases $K_{\mathrm{d}}$ (reduces binding affinity) and increases the level of cell surface expression. However, there is one exception, in which the level of cell surface expression decreased in the truncated 80 aa G-terminal tail receptor. These data may explain the drastic decrease in signaling of the truncated 80 aa C-terminal tail receptor, which likely results from a combination of decreased binding affinity and cell surface expression. Alternatively, the recovery of cAMP accumulation that was seen 
when the lamprey GnRH receptor with a 40 aa tail was activated may be due to the increase in cell surface expression, which compensates for the reduction in binding affinity. Finally, the fully truncated tail-less receptor was shown to maintain ligand-binding capability at a diminished binding affinity, which, despite an increase in surface expression, led to the accumulation of near basal levels of cAMP. Because the tail-less lamprey GnRH receptor mutant is known to be active in stimulating $\mathrm{IP}_{3}$ at an equivalent magnitude compared with wild type (Silver et al. 2005), these data support the hypothesis that $\mathrm{G} \alpha_{\mathrm{s}}$ coupling occurs within the first 40 aa of the C-terminal tail.

Rapid, ligand-dependant GPCR internalization is a well-established regulatory mechanism that results in receptor desensitization or alternatively facilitates signal switching from G-protein-mediated second messaging to MAP kinase signaling (McArdle et al. 2002). Activation of type II GnRH receptors has been extensively shown to lead to rapid internalization that can be $\beta$-arrestin dependent or independent, dynamin dependent or independent and through either clathrin coated vesicles or caveolae (Acharjee et al. 2002, Pawson et al. 2003, Ronacher et al. 2004, Hislop et al. 2005). Type I GnRH receptors have been shown to be internalized but at a significantly slower rate and to a lesser extent when compared with type II GnRH receptors (Pawson et al. 1998, Willars et al. 1999, Hislop et al. 2005). Addition of the C-terminal tail from the type II catfish GnRH receptor to the rat GnRH receptor was shown to result in several functional aberrations, most notably induction of rapid ligand-dependant internalization, which was shown to be reversible through C-terminal tail truncations (Lin et al. 1998). Furthermore, removal of the C-terminal tail from the type II chicken GnRH receptor was shown to result in an internalization profile similar to the naturally tail-less human type I GnRH receptor (Pawson et al. 1998). These studies provided the impetus to further define the motifs involved in this rapid internalization, leading to a series of studies indicating specific Ser/Thr moieties located in both the membrane proximal or distal regions of the C-terminal tail (Blomenrohr et al. 1999, Pawson et al. 2003, Millar et al. 2004, Ronacher et al. 2004). The 120 aa C-terminal tail of the lamprey GnRH receptor, the longest of any known GnRH receptor (Silver et al. 2005), contains several Ser/Thr residues located throughout the entire sequence; however, they are concentrated within the first 40 aa. The lamprey GnRH receptor was shown to be rapidly internalized in response to stimulation, whereas approximately $60 \%$ of the ligand-bound receptors were located in the intracellular space. Truncation of the C-terminal tail to 80 aa or 40 aa had no effect on internalization (rate or maximum level) but the tail-less mutant showed a drastic reduction in internalization, similar to other previously described tail-less receptor internalization profiles (Heding et al. 1998, Pawson et al. 1998). It should be noted that these internalization profiles were generated using lamprey GnRH-I because of the inability to iodinate lamprey GnRH-III, which lacks a tyrosine residue. The use of lamprey GnRH-I in these experiments may lead to different results compared with lamprey GnRH-III stimulation of the lamprey GnRH receptor; however, these differences would likely be reflected in the magnitude of responses and not novel response profiles.

In summary, the lamprey GnRH receptor was shown to activate the cAMP signaling system, which required the first 40 aa of the C-terminal tail. Pharmacological profiling, in conjunction with efficacy data, provided evidence that the lamprey GnRH receptor is lamprey GnRH-III selective, which supports the hypothesis that the lamprey expresses a second, lamprey GnRH-I selective receptor. Truncations of the lamprey GnRH receptor's C-terminal tail were shown to reduce binding affinity, which explains their reductions in signaling capacity. Finally, the lamprey GnRH receptor underwent rapid ligand-dependant internalization, which was drastically reduced in the tail-less mutant form, suggesting that putative phosphoacceptor sites located within the first 40 aa of the C-terminal tail are required for this regulatory mechanism. Since the 40 aa C-terminal tail lamprey GnRH receptor mutant is capable of stimulating both $\mathrm{IP}_{3}$ (Silver et al. 2005) and cAMP accumulation and undergoes rapid liganddependant internalization, given the results of these studies we propose that the extensive length of the lamprey GnRH receptor $\mathrm{C}$-terminal tail may not have a functional significance with these signaling systems. However, the intact lengthy lamprey GnRH receptor G-terminal tail likely reflects an ancestral characteristic and may be required for structural stability, efficient ligand binding and/or stimulation of another unknown signaling pathway. Further detailed mutagenic studies need to be done to determine the function of the G-terminal tail of the lamprey $\mathrm{GnRH}$ receptor. In conclusion, the data from the current and previous studies indicate that the lamprey GnRH receptor shares several characteristics of both type I and type II GnRH receptors, suggesting that it retains ancestral characteristics of the vertebrate GnRH receptor family.

\section{Acknowledgements}

This research was supported by NSF grant 0421923 (to S A S), and is scientific contribution number 2282 from the New Hampshire Agricultural Experiment Station. We would like to thank Scott I Kavanaugh for his assistance with iodinations. The authors declare that there is no conflict of interest that would prejudice the impartiality of this scientific work. 


\section{References}

Acharjee S, Maiti K, Soh JM, Im WB, Seong JY \& Kwon HB 2002 Differential desensitization and internalization of three different bullfrog gonadotropin-releasing hormone receptors. Molecules and Cells 14 101-107.

Arora KK, Sakai A \& Catt KJ 1995 Effects of second intracellular loop mutations on signal transduction and internalization of the gonadotropin-releasing hormone receptor. Fournal of Biological Chemistry $27022820-22826$.

Arora KK, Cheng Z \& Catt KJ 1997 Mutations of the conserved DRS motif in the second intracellular loop of the gonadotropinreleasing hormone receptor affect expression, activation, and internalization. Molecular Endocrinology 11 1203-1212.

Arora KK, Krsmanovic LZ, Mores N, O'Farrell H \& Catt KJ 1998 Mediation of cyclic AMP signaling by the first intracellular loop of the gonadotropin-releasing hormone receptor. Fournal of Biological Chemistry 273 25581-25586.

Blomenrohr M, Heding A, Sellar R, Leurs R, Bogerd J, Eidne KA \& Willars GB 1999 Pivotal role for the cytoplasmic carboxylterminal tail of a nonmammalian gonadotropin-releasing hormone receptor in cell surface expression, ligand binding, and receptor phosphorylation and internalization. Molecular Pharmacology $\mathbf{5 6}$ 1229-1237.

Bockaert J, Marin P, Dumuis A \& Fagni L 2003 The 'magic tail' of $\mathrm{G}$ protein-coupled receptors: an anchorage for functional protein networks. FEBS Letters 546 65-72.

Brothers SP, Janovick JA, Maya-Nunez G, Cornea A, Han XB \& Conn PM 2002 Conserved mammalian gonadotropin-releasing hormone receptor carboxyl terminal amino acids regulate ligand binding, effector coupling and internalization. Molecular and Cellular Endocrinology $19019-27$.

Chung HO, Yang Q Catt KJ \& Arora KK 1999 Expression and function of the gonadotropin-releasing hormone receptor are dependent on a conserved apolar amino acid in the third intracellular loop. Fournal of Biological Chemistry 274 35756-35762.

Deragon KL \& Sower SA 1994 Effects of lamprey gonadotropinreleasing hormone-III on steroidogenesis and spermiation in male sea lampreys. General and Comparative Endocrinology 95 363-367.

Fredriksson R, Hoglund PJ, Gloriam DE, Lagerstrom MC \& Schioth HB 2003 Seven evolutionarily conserved human rhodopsin G protein-coupled receptors lacking close relatives. FEBS Letters 554 381-388.

Grosse R, Schmid A, Schoneberg T, Herrlich A, Muhn P, Schultz G \& Gudermann T 2000 Gonadotropin-releasing hormone receptor initiates multiple signaling pathways by exclusively coupling to G(q/11) proteins. Fournal of Biological Chemistry 275 9193-9200.

Hazum E, Meidan R, Liscovitch M, Keinan D, Lindner HR \& Koch Y 1983 Receptor-mediated internalization of LHRH antagonists by pituitary cells. Molecular and Cellular Endocrinology 30 291-301.

Heding A, Vrecl M, Bogerd J, McGregor A, Sellar R, Taylor PL \& Eidne KA 1998 Gonadotropin-releasing hormone receptors with intracellular carboxyl-terminal tails undergo acute desensitization of total inositol phosphate production and exhibit accelerated internalization kinetics. Fournal of Biological Chemistry 273 $11472-11477$.

Hislop JN, Caunt CJ, Sedgley KR, Kelly E, Mundell S, Green LD \& McArdle CA 2005 Internalization of gonadotropin-releasing hormone receptors (GnRHRs): does arrestin binding to the C-terminal tail target GnRHRs for dynamin-dependent internalization? Fournal of Molecular Endocrinology 35 177-189.

Ikemoto T, Enomoto M \& Park MK 2004 Identification and characterization of a reptilian $\mathrm{GnRH}$ receptor from the leopard gecko. Molecular and Cellular Endocrinology 214 137-147.

King JA, Fidler A, Lawrence S, Adam T, Millar RP \& Katz A 2000 Cloning and expression, pharmacological characterization, and internalization kinetics of the pituitary GnRH receptor in a metatherian species of mammal. General and Comparative Endocrinology $117439-448$

Kitanovic S, Yuen T, Flanagan CA, Ebersole BJ \& Sealfon SC 2001 Insertional mutagenesis of the arginine cage domain of the gonadotropin-releasing hormone receptor. Molecular Endocrinology 15 390-397.

Knox CJ, Boyd SK \& Sower SA 1994 Characterization and localization of gonadotropin-releasing hormone receptors in the adult female sea lamprey, Petromyzon marinus. Endocrinology 134 492-498.

Koenig JA \& Edwardson JM 1997 Endocytosis and recycling of G protein-coupled receptors. Trends in Pharmacological Sciences 18 276-287.

Lin X, Janovick JA, Brothers S, Blomenrohr M, Bogerd J \& Conn PM 1998 Addition of catfish gonadotropin-releasing hormone $(\mathrm{GnRH})$ receptor intracellular carboxyl-terminal tail to rat $\mathrm{GnRH}$ receptor alters receptor expression and regulation. Molecular Endocrinology 12 161-171.

Liu F, Austin DA, Mellon PL, Olefsky JM \& Webster NJ 2002 Involvement of both $\mathrm{Gq} / 11$ and $\mathrm{Gs}$ proteins in gonadotropinreleasing hormone receptor-mediated signaling in Lbeta T2 cells. fournal of Biological Chemistry 277 32099-32108.

McArdle CA, Franklin J, Green L \& Hislop JN 2002 Signalling, cycling and desensitisation of gonadotrophin-releasing hormone receptors. Fournal of Endocrinology 173 1-11.

Millar RP, Lu ZL, Pawson AJ, Flanagan CA, Morgan K \& Maudsley SR 2004 Gonadotropin-releasing hormone receptors. Endocrine Reviews 25 235-275.

Myburgh DB, Millar RP \& Hapgood JP 1998 Alanine-261 in intracellular loop III of the human gonadotropin-releasing hormone receptor is crucial for G-protein coupling and receptor internalization. Biochemical fournal 331 893-896.

Oh DY, Song JA, Moon JS, Moon MJ, Kim JI, Kim K, Kwon HG \& Seong JY 2005 Membrane-proximal region of the carboxyl terminus of the gonadotropin-releasing hormone receptor (GnRHR) confers differential signal transduction between mammalian and nonmammalian GnRHRs. Molecular Endocrinology 19 722-731.

Okubo K, Nagata S, Ko R, Kataoka H, Yoshiura Y, Mitani H, Kondo M, Naruse K, Shima A \& Aida K 2001 Identification and characterization of two distinct GnRH receptor subtypes in a teleost, the medaka Oryzias latipes. Endocrinology 142 $4729-4739$.

Pawson AJ, Katz A, Sun YM, Lopes J, Illing N, Millar RP \& Davidson JS 1998 Contrasting internalization kinetics of human and chicken gonadotropin-releasing hormone receptors mediated by C-terminal tail. Fournal of Endocrinology 156 R9-R12.

Pawson AJ, Maudsley SR, Lopes J, Katz A, Sun YM, Davidson JS \& Millar RP 2003 Multiple determinants for rapid agonistinduced internalization of a nonmammalian gonadotropinreleasing hormone receptor: a putative palmitoylation site and threonine doublet within the carboxyl-terminal tail are critical. Endocrinology 144 3860-3871.

Ronacher K, Matsiliza N, Nkwanyana N, Pawson AJ, Flanagan CA, Millar RP \& Katz AA 2004 Serine residues 338 and 339 in the carboxyl-terminal tail of the type II gonadotropin-releasing hormone receptor are critical for beta-arrestin-independent internalization. Endocrinology 145 4480-4488.

Sealfon SC, Weinstein H \& Millar RP 1997 Molecular mechanisms of ligand interaction with the gonadotropin- releasing hormone receptor. Endocrine Reviews 18 180-205.

Sherwood NM, Sower SA, Marshak DR, Fraser BA \& Brownstein MJ 1986 Primary structure of gonadotropin-releasing hormone from lamprey brain. Fournal of Biological Chemistry $2614812-4819$.

Sherwood NM, von Schalburg KR \& Lescheid D 1997 Origin and evolution of $\mathrm{GnRH}$ in vertebrates and invertebrates. In $\mathrm{GnRH}$ Neurons: Gene to Behavior, pp 3-25. Eds IS Parhar \& Y Sakuma. Tokyo: Brain Shuppan. 
Silver MR, Kawauchi H, Nozaki M \& Sower SA 2004 Cloning and analysis of the lamprey GnRH-III cDNA from eight species of lamprey representing the three families of Petromyzoniformes. General and Comparative Endocrinology 139 85-94.

Silver MR, Nucci NV, Root AR, Reed KL \& Sower SA 2005 Cloning and characterization of a functional type II gonadotropinreleasing hormone receptor with a lengthy carboxy-terminal tail from an ancestral vertebrate, the sea lamprey. Endocrinology 146 $3351-3361$.

Sower SA 1997 Evolution of GnRH in fish of ancient origins. In GnRH Neurons: Gene To Behavior, pp 27-49. Eds IS Parhar \& Y Sakuma. Tokyo: Brain Shuppan.

Sower SA 2003 The endocrinology of reproduction in lampreys and applications for male lamprey sterilization. Fournal of Great Lakes Research 29 (Suppl 1) 50-65.

Sower SA, Chiang YC, Lovas S \& Conlon JM 1993 Primary structure and biological activity of a third gonadotropin-releasing hormone from lamprey brain. Endocrinology 132 1125-1131.

Stanislaus D, Ponder S, Ji TH \& Conn PM 1998 Gonadotropinreleasing hormone receptor couples to multiple $\mathrm{G}$ proteins in rat gonadotrophs and in GGH3 cells: evidence from palmitoylation and overexpression of G proteins. Biology of Reproduction $\mathbf{5 9}$ 579-586.
Stopa EG, Sower SA, Svendsen CN \& King JC 1988 Polygenic expression of gonadotropin-releasing hormone $(\mathrm{GnRH})$ in human? Peptides 9 419-423.

Suzuki K, Gamble RL \& Sower SA 2000 Multiple transcripts encoding lamprey gonadotropin-releasing hormone-I precursors. Fournal of Molecular Endocrinology 24 365-376.

Ulloa-Aguirre A, Stanislaus D, Arora V, Vaananen J, Brothers S, Janovick JA \& Conn PM 1998 The third intracellular loop of the rat gonadotropin-releasing hormone receptor couples the receptor to Gs- and G(q/11)-mediated signal transduction pathways: evidence from loop fragment transfection in GGH3 cells. Endocrinology $1392472-2478$.

Vrecl M, Heding A, Hanyaloglu A, Taylor PL \& Eidne KA 2000 Internalization kinetics of the gonadotropin-releasing hormone $(\mathrm{GnRH})$ receptor. Pflugers Archiv 439 (Suppl 3) R19-R20.

Willars GB, Heding A, Vrecl M, Sellar R, Blomenrohr M, Nahorski SR \& Eidne KA 1999 Lack of a C-terminal tail in the mammalian gonadotropin-releasing hormone receptor confers resistance to agonist-dependent phosphorylation and rapid desensitization. Fournal of Biological Chemistry 274 30146-30153.

Received in final form 1 February 2006 Accepted 6 March 2006 